\title{
Life Experience of Ethnic Minorities in Urban of Vietnam: An Analysis of the Social Relationship and Social Networks
}

\author{
Nguyen Van Chieu \\ VNU-University of Social Sciences and Humanities, \\ 336 Nguyen Trai Street, Thanh Xuan District, \\ Hanoi, Vietnam \\ Tran Van Kham \\ VNU-University of Social Sciences and Humanities, \\ 336 Nguyen Trai Street, Thanh Xuan District, Hanoi, Vietnam; \\ National Ageing Research Institute, Royal Melbourne Hospital, \\ Royal Park Campus, Gate 4, Building 8, 34-54 Poplar Rd, Parkville VIC 3052, Australia; \\ University of South Australia, 101 Currie St, Adelaide SA 5001, Australia
}

DOI: https://doi.org/10.36941/jesr-2021-0119

\section{Abstract}

This article is a part of a research project supported by Vietnam National University-Hanoi about the social welfare of ethnic people in the urban and industrial zones, aims at identifying and describing the life experiences of these groups in the urbanization process. Shreds of evidence from analysing the social network, social connection, social interaction of research participants in their living and working places, it is found that the ethnic minorities face difficulties in setting their life in the new context. However, they tend to build the social cohesion and to be satisfied with the new life conditions to meet the objectives of having a better life and a job in the new context. The findings from this analysis also show that there is a difference among the living place, age group, gender correlated to the social network, social relation and life experiences in the new context. It is the initial finding from the survey of 6oo ethnic people in urban of three provinces of Daklak, Lang Son and Binh Duong of Vietnam.

Keywords: Ethnic minority; Urban; Industrial Zones; Social Relations; Social Experiences; Vietnam

\section{Introduction}

Vietnam is a country with 54 ethnic minority groups, each of which has its own economic, potential, cultural identity and language. They mostly reside and live in mountainous areas, with a few in the delta, spread over three fourth of the country. Recent findings from GSO (2016) show that the whole country has 171,817 enumeration areas (where the number of ethnic minorities is at $30 \%$ or more of the total area population), in which there are 3,380 urban areas and 27,556 rural areas. The number of ethnic minorities has increased significantly from 2009 through 2015, with an average rate at $1.55 \%$ annually. The number of ethnic minorities currently living in 3,040 households and the increased 
ratio of the family is around $1.6 \%$ annually (GSo 2016). With such population size, the number of ethnic minority people living in urban areas of Vietnam accounts for about 10.4\% (GSO 2016). The need for a system of support policies, research on ethnic minority life in general and their presence in the industrial zones and urban in particular is an important topic, aiming to promote the social supports, social inclusion, and create the measures to reduce the inequality in development opportunities. This paper is a part of the project number QG.1847 funded by Vietnam National University, Hanoi (VNU) identifies the real picture of the life experiences by ethnic minorities in aspects of social relationships and social interactions. By which, it suggests the implications for supporting activities to promote the participation of ethnic minorities in the urban life and development of social welfare for them.

\section{Literature Review}

The living conditions of ethnic minorities in urban areas in Vietnam today are one of the most urgent challenges in social development. As they have few opportunities to choose social services including employment due to the economic, cultural and social conditions. Recent studies on the life of ethnic minorities in the urban are viewed as the following aspects:

In urban and industrial areas, the poor is the one most vulnerable to environmental degradation (World Bank 2012, p.17). Meanwhile, the implementation of the subsidy policy does not always reach the urban poor promptly. Reducing risks for the poor in general and ethnic minorities in particular in the urban requires excellent and sustainable growth policies which are adapted to the reality and specific characteristics of the urban life. That needs reforming and renewing on service provision, public investment, and completing the social-economic infrastructure in the urban. Recognising the issue of ensuring social welfare and security for people in general and ethnic minorities in particular in the urban is an essential and significant welfare issue which is a significant point in the sustainable development strategy of Vietnam (Pham Van Duc et al. 2010). In this research, the aspect of social welfare development and sustainability are considered as essential prerequisites to address the other social welfare issues in the current life (Pham Van Duc et al., 2010, p.11). In the research of social welfare in Vietnam, it emphasised that social security becomes a central issue in the country's development strategy. It is implemented by taking care, unceasing the improvement of material and spiritual life of the people which is the highest goal of the cause of socialist construction in Vietnam (Vu Van Phuc, 2012, pp.13-14). It can be found that although each research has a different approach, it has the same purpose of providing solutions to continuously improve the life for people, ensuring the sustainable development (Nguyen Van Chieu 2013).

In addition to the research trend on social security, there are also studies on the situation of the lives of ethnic minorities in urban areas with two main aspects: national-scale studies with several national representative samples, such as population census, survey of living standards; and sampling studies with focusing in urban economy, urban planning, urban culture and lifestyle. In general, this research direction has the advantage of drawing out the characteristics of the process, the specific aspects of urban life to a certain extent. However, this research direction has the disadvantage of having many analytical criteria, less reflecting the characteristics of urban life nationwide. In these studies, the migrant is studied from different perspectives, such as the size of migration flows, the structure of immigrants (Le Bach Duong and Nguyen Thanh Liem 2011). At the same time, studying the effects of urbanization and modernization on the life of ethnic minorities is also of particular interest. These concerns are identified on the cultural life of ethnic minorities in the process of industrialization (Tran Van Binh 2004, Tran Van Binh 2006). In additions, there is research on labour and employment of workers in industrial zones in the northern key economic regions (Ta Thi Doan 2011); and the relationship between ethnic issues and the orientation to formulate ethnic policies in the period of industrialization and modernization (Be Truong Thanh 2002). Dinh Quang et al (2005) introduced the process and characteristics of urbanization in Vietnam and the social-cultural situation in the urban areas. Besides, social-psychological issues of workers in different types of 
enterprises were also mentioned (Nguyen Van Nhat et al. 2010, Phan Thi Mai Huong et al., 2013). These researches presented the role and status of workers in society and businesses; worker's perception of government policies towards them and significant issues of the country, life and employment, awareness and behaviour of worker with improving skills, the relationship between leaders and workers in different types of business. La Thi Thu Thuy et al., (2011) described the psychological changes of young workers coming from rural areas as well as changes in housing needs, cultural and spiritual activities, awareness and communication, and adaptation to the urban lifestyle. In specific directions, Tran Thanh Nam (2011) mentioned the spiritual life of Khmer ethnic minority in the renovation process which creates the theoretical basis for analysing the needs and trends on developing the spiritual life for ethnic minorities in the renovation process. And Nguyen Minh Tuan (2013), through research of the life of Ede ethnic group in Daklak, identified the theoretical basis for researching the life changes among ethnic minority groups. This research describes the life condition of Ede ethnic group in two aspects: (i) economic: infrastructure, housing condition, household living amenities, household income, and (ii) non-economic: education, health, recreation, community activities and gender equality.

Besides, Nguyen Van Quyet (2013) in studying the cultural changes of agricultural-rural communities in the process of industrialization, presented the current situation of change in the cultural life of the rural community into the urban life. It also mentions to the changes in the ethics, morality and makes suggestions on having the policies on cultural administration. Researching in cultural changes in the residential community in the urban, Nguyen Dinh Tuan (2013), through research in Hanoi, explores some cultural changes in the community. Tran Nguyet Minh Thu (2014), from findings of the integration process in the urban by free migrant of rural workers in Hanoi, focused on the life of migrants in urban, analyse the current situation of integration in the urban community of the free rural migrant workers. In additions, there are research works about exchanging ideas on the lives of ethnic minorities in the urban areas (Ngo Thi Trinh 2014, Ha Son Nhin 2014, Pham Ngoc Phuong 2014, Dang Phu Thau 2014), while some other studies mentioned more clearly on how to ensure the life in industrial zones for workers (Nguyen Van Du 2006, Nguyen Quang Dieu 2006, Tran Van Chu 2007, Van Tao 2007). A recent paper by Nguyen Van Chieu and Tran Van Kham (2013) focused on the general picture of social welfare for ethnic minority's migrants in the urban.

It can be seen that, in recent studies on the lives of ethnic minorities in urban areas, there is lack of specific studies to identify the social issues, social networks and social experiences in the urban areas. These are significant aspects which need attention as they promote the participation and integration of ethnic minorities in the new habitats, and they are ways for agencies and organisations to manage better and develop the role and involvement of ethnic minorities. To have full participation in urban life, ethnic minorities have more condition to work towards a better life in a new living context.

\section{Methodology and Methods}

\subsection{Research approaches}

This research applies three approaches to identifying the social connection of ethnic minorities in urban life:

Firstly, access to the lives of ethnic minorities in urban-based on the review of human development: Human development is the process of expanding opportunities for people to improve the quality of life in a sustainable way (Wattez 1999). The perspective of human development sees the capacity to live a meaning life as an essential goal. As a middle-income country, Vietnam currently has many new development opportunities. However, many challenges need to be addressed, especially if Vietnam wants to overcome the social called "middle-income trap". These include underdeveloped infrastructure and levels of specialisation, and poor competitiveness, weak scientific 
and technological level, and lack of skilled workforce. Therefore, a new development approach is needed if Vietnam wants to achieve quality and sustainable growth. In particular, Vietnam needs to focus not only on raising incomes but also on improving human development through the provision of higher quality health and education services, creating decent jobs for a growing young workforce, strengthening governance and building reliable and effective institutions (UNDP 2011).

Secondly, access to the essential services of ethnic minorities in the urban based on the reviews of human capital and social capital: Human capital means the potentiality and ability to generate the health and knowledge to have the better future benefits. Bardhan và Udry (1999) said that human capital is one of the significant factors creating a higher income and living standard as any other assets, especially for poor people. It is the rational concept for making and selecting the criteria framework for analysing the life experiences of ethnic minorities in the urban of Vietnam. The social capital, as a social relationship in term of kinship, community or friendship, is vital in helping the ethnic minority to improve their life and their adaptation in the new living contexts. It is a significant research direction with less given concerns in Vietnam currently.

Thirdly, access to the welfare services of ethnic minorities in urban based on the concept of sustainable livelihoods. This concept is developed from the "Sustainable Livelihoods Guidance Sheets" by DFID in 1999, with reference on promoting the policies and actions for sustainable livelihoods and poverty reduction (DFID 1999; Nguyen Van Suu 2010). Besides, the social inclusion approach is also the current trend to identify the social barriers which an individual is facing. Social inclusion is reviewed in the following aspects: (i) social pressure: low household income, rental price, pressure on purchasing household appliances, single-parent family model; (ii) health: low birth weight, childhood injury, immunization, disability, illness assistance, life expectancy, number of people with a mental health condition, suicide rate; (iii) community safety: number of child abuse, crimes, number of imprisoned, number of domestic violence cases; (iv) economy: number of unskilled workers, unemployment, longterm unemployment, ratio of dependants, low income, limited access to information/internet; (v) education: illiteracy rate, school incompletion, early school leaving ratio, post highschool level; (vi) community participation: with different aspects of community activities (Tran Van Kham 2011). These indicators also need to be measured to identify individual inclusion in the current life context of the community. Therefore, it aims to have a specific way of identifying the lives of ethnic minorities in the urban from the perspective of life experiences of ethnic minorities.

\subsection{Data collection and analysis}

This research uses the following methods on collecting the primary and secondary data to provide specific evidence for the current picture of social relationship among ethnic minorities in urban:

- Document analysis: the focus of this method is mainly on the (i) systematic guidelines and policies related to ethnic minorities, urbanization and common issues raised to ethnic minorities, (ii) research works related to the lives of ethnic minorities in aspects of community participation, employment among ethnic minorities, (iii) research related to urban development, job creation for ethnic minorities; (iv) report, data and annual statistic books about the life of ethnic minorities in the urban. This method is applied to maximize the evidence for designing the research framework, analysing the context and proposing the related measures. In additions, implications from the recent research also support the theoretical perspective for researching the social relationship among the ethnic minorities in the urban life of Vietnam.

- Primary data collection: this article uses data from the research project funded by Vietnam National University-Hanoi. There are quantitative and qualitative data: the former is developed from the in-depth interviews, while the latter is collected from the survey in three provinces of Son La, Daklak and Binh Duong where the urbanization is occurring with a 
quick pace. Each locality, 200 ethnic minorities over the age of 18 were selected for this study. The content of this research aims at accessing the living conditions of ethnic minorities in the urban; identifying those factors affecting the implementation of policies and solutions to improve the lives of ethnic minorities in the urban areas in this country. The sample of surveying is described in Table 1 as following:

Table 1: Survey sample

\begin{tabular}{|c|c|c|c|c|c|c|c|c|}
\hline & & $\mathrm{N}$ & $\%$ & Min & Max & Mean & SD & Mode \\
\hline & Gender & 599 & 100 & & & & & \\
\hline \multirow[t]{4}{*}{1} & Male & 294 & 49.1 & & & & & \\
\hline & Female & 305 & 50.9 & & & & & \\
\hline & Marital status & 598 & 100 & & & & & \\
\hline & Never married & 177 & 29.6 & & & & & \\
\hline \multirow[t]{5}{*}{2} & Married & 397 & 66.4 & & & & & \\
\hline & Divorced/Separated & 10 & 1.7 & & & & & \\
\hline & Widowed & 14 & 2.3 & & & & & \\
\hline & Age group & 598 & 100 & 16 & 69 & 33.12 & 11.66 & 30 \\
\hline & Under 30 & 303 & 50.7 & & & & & \\
\hline \multirow{8}{*}{3} & From 30 to under 45 & 190 & 31.8 & & & & & \\
\hline & 45 and above & 105 & 17.6 & & & & & \\
\hline & Ethnic minority group & 601 & 100 & & & & & \\
\hline & No answer & 5 & 0.8 & & & & & \\
\hline & Cao Lan & 1 & 0.2 & & & & & \\
\hline & Dao & 20 & $3 \cdot 3$ & & & & & \\
\hline & Ede & 199 & 33.1 & & & & & \\
\hline & Giay & 1 & 0.2 & & & & & \\
\hline \multirow[t]{8}{*}{4} & Khme & 196 & 32.6 & & & & & \\
\hline & H'mong & 16 & 2.7 & & & & & \\
\hline & Muong & 10 & 1.7 & & & & & \\
\hline & Nung & 23 & 3.8 & & & & & \\
\hline & San Diu & 48 & 8.0 & & & & & \\
\hline & Tay & 76 & 12.6 & & & & & \\
\hline & Thai & 6 & 1.0 & & & & & \\
\hline & Residential model & 599 & 100 & & & & & \\
\hline \multirow[t]{3}{*}{5} & Migrating & 238 & 39.7 & & & & & \\
\hline & Permanent & 361 & 60.3 & & & & & \\
\hline & Province & 601 & 100 & & & & & \\
\hline \multirow{3}{*}{6} & Son La & 200 & 33.3 & & & & & \\
\hline & Daklak & 201 & 33.4 & & & & & \\
\hline & Binh Duong & 200 & 33.3 & & & & & \\
\hline & Time living in the study area (month) & 591 & 100 & 1 & 720 & 211.61 & $225 \cdot 53$ & 24 \\
\hline
\end{tabular}

\section{Findings and Discussions}

In order to explore the level of social experiences that ethnic minorities express their lives and workplace, there are seven questions to measure. These questions cover the following aspects: number of friends (with different groups of people), the extent of visits and being visited with individual social networks, how to solve the life difficulties, the extent to which they are invited to participate and actively participate in social and community activities, activities in the leisure time, social issue experiences in living context and practices in workplaces. The significant findings are identified as followed: 


\subsection{Number of friends among ethnic minorities}

The number of friends among an ethnic minority is explored as in Table 2:

Table 2: Number of friends among an ethnic minority person

\begin{tabular}{llcccc}
\hline & $\mathrm{N}$ & Min & Max & Mean & SD \\
\hline $\mathbf{1}$ Friends are indigenous people & $5 \mathrm{O} 7$ & $\mathrm{o}$ & 100 & 8.82 & 14.03 \\
\hline $\mathbf{2}$ Friends are migrants from the same home countryside & 503 & $\mathrm{o}$ & 100 & 8.14 & 13.67 \\
\hline 3 Friends are other migrants & 498 & $\mathrm{o}$ & $\mathbf{2 0 0}$ & 8.27 & 17.51 \\
\hline Total & 538 & $\mathrm{o}$ & $\mathbf{2 0 0}$ & 8.75 & 16.27 \\
\hline
\end{tabular}

The average number of friends in the relationship of ethnic minorities is 8.75. This figure is similar in the form of indigenous friends, other migrants and those migrants from the same countryside. However, in the survey data, the indicator of "no friend" is most appeared when talking about friends in their social relationships. Interestingly, friends from the same countryside are lower than other forms of friendship in this study.

\subsection{Level of visiting and being visited in daily interaction among ethnic minorities}

Table 3: Level of visiting in term of social relationship among ethnic minorities

\begin{tabular}{|c|c|c|c|c|c|c|c|}
\hline & Visiting & $\mathrm{N}$ & Min & Max & Mean & SD & Mode \\
\hline 1 & Relatives in the city & 588 & 1 & 5 & 2.53 & 1.24 & 1 \\
\hline 2 & Friends in the city & 591 & 1 & 5 & 2.58 & 1.09 & 3 \\
\hline 3 & People from the same countryside & 582 & 1 & 5 & 2.46 & 1.10 & 3 \\
\hline 4 & Same neighbours & 576 & 1 & 5 & 2.59 & 1.27 & 1 \\
\hline 5 & Workmates & 578 & 1 & 5 & 2.57 & 1.12 & 3 \\
\hline 6 & Local people & 575 & 1 & 5 & 2.22 & 1.02 & 3 \\
\hline 7 & Local government & 582 & 1 & 5 & 1.88 & 0.94 & 1 \\
\hline 8 & Local mass organisation & 576 & 1 & 5 & 1.88 & 0.94 & 1 \\
\hline & Total & & & & 2.35 & 0.82 & \\
\hline & Son La & & & & 2.22 & 0.96 & \\
\hline & Daklak & & & & 2.69 & 0.74 & \\
\hline & Binh Duong & & & & 2.12 & 0.60 & \\
\hline
\end{tabular}

Note: the significant level of mean is calculated as (5-1)/5 equals to 0.8 , so the level of less than 1.8 is very infrequent, from 1.8 to less than 2.6 is infrequent, from 2.6 to less than 3.4 is normal, from 3.4 to less than 4.2 is frequent, and above 4.2 is very frequent.

It can be seen that ethnic minorities do not often make visits to relatives, friends, workmates or neighbours in the process of working and living in the urban areas. It is noted that the most infrequent level of interaction is the connection with local government and local organisations, but when identifying the level of concentration of responses and opinions revolve around the normal levels in visiting a friend in the city, the people from the same countryside, workmates, and local people. In terms of visiting these objects, ethnic minorities in Daklak tend to exhibit normal levels while those in Binh Duong and Son Lan show infrequent level. The permanent/local ethnic minorities still tend to have a friend and relative visits. 
Table 4: The level of being visited among the ethnic minorities in urban

\begin{tabular}{llcccccc}
\hline & Being visited & $\mathrm{N}$ & Min & Max & Mean & SD & Mode \\
\hline $\mathbf{1}$ & Relatives in the city & 488 & 1 & 5 & 2.22 & 1.12 & 1 \\
\hline $\mathbf{2}$ & Friends in the city & 488 & 1 & 5 & 2.51 & 1.16 & 3 \\
\hline 3 & People from the same countryside & 483 & 1 & 5 & 2.30 & 1.13 & 1 \\
\hline 4 & Same neighbours & 469 & 1 & 5 & 2.45 & 1.27 & 1 \\
\hline 5 & Workmates & 474 & 1 & 5 & 2.37 & 1.06 & 3 \\
\hline 6 & Local people & 477 & 1 & 5 & 2.07 & 0.95 & 1 \\
\hline 7 & Local government & 478 & 1 & 5 & 1.80 & 0.89 & 1 \\
\hline 8 & Local mass organisation & 479 & 1 & 5 & 1.77 & 0.91 & 1 \\
\hline Total & & & & 2.22 & $\mathbf{0 . 8 1}$ & \\
\hline Son La & & & & 2.34 & 1.06 & \\
\hline Dak Lak & & & & 2.10 & 0.46 & \\
\hline Binh Duong & & & & & \\
\hline
\end{tabular}

Note: the significant level of mean is calculated as: (5-1):5 equals to 0.8 , so the level of less than 1.8 is very infrequent, from 1.8 to less than 2.6 is infrequent, from 2.6 to less than 3.4 is normal, from 3.4 to less than 4.2 is frequent, and above 4.2 is very frequent.

It is found that being visited is lower than going visiting in most relationship. There is also a difference among regions, ethnic minorities in Son La are being visited by other friends with a higher level than those in Binh Duong and Dak Lak, but it is still at the level of infrequent. Thus, in comparison with the above table of 3 , it is possible to identify a part of the objective activeness in the social relationship of ethnic minorities. An analysis of the regional difference, being visited and going to visit among ethnic minorities in Dak Lak, it is found that the local ethnic minorities show precise degree. In contrast, those in Binh Duong show the lower level.

Ethnic minorities spend more time at work and pay less attention to social relations and community activities. It is identified in many interviews with leaders and ethnic minorities. Some interview extractions are supportive of this argument as:

"In recent years, the youth union of the local ward has created a place for migrated workers and their families to participate through the Project of Gathering young workers of Binh Duong Youth Union between 2011 and 2016. The male workers prefer to music and art performance, while the female ones like legal and reproductive health propaganda. These activities are low efficiency and do not make many changes in their life " (VQD, 48 years old, Thu Dau Mot City, Binh Duong Province."

"I rarely participate in activities in the community, as I work for 10 to 12 hours per day, at leisure time, I only prefer to sleep " (VHT, 23 years old, man, Lao Cai).

\subsection{Method of solving difficulties}

Table 5: Ways to solve difficulties

\begin{tabular}{|c|c|c|c|c|c|c|}
\hline & $\mathrm{N}$ & Min & Max & Mean & SD & Mode \\
\hline 1 Self-solving & 592 & 1 & 5 & 4.28 & 0.91 & 5 \\
\hline 2 Calling to relatives in the countryside & 543 & 1 & 5 & 2.56 & 1.26 & 1 \\
\hline 3 Asking supports from relatives in the city & 537 & 1 & 5 & 2.44 & 1.10 & 3 \\
\hline 4 Asking supports from migrants from the same countryside & 536 & 1 & 5 & 2.25 & 1.11 & 1 \\
\hline 5 Asking supports from workmates & 532 & 1 & 5 & 2.46 & 1.08 & 3 \\
\hline 6 Asking supports from local people & 538 & 1 & 5 & 2.19 & 1.06 & 1 \\
\hline 7 Asking supports from local government & 539 & 1 & 5 & 1.97 & 1.04 & 1 \\
\hline 8 Asking supports from local unions & 538 & 1 & 5 & 1.93 & 0.97 & 1 \\
\hline
\end{tabular}

Note: the significant level of mean is calculated as: (5-1):5 equals to 0.8 , so the level of less than 1.8 is very infrequent, from 1.8 to less than 2.6 is infrequent, from 2.6 to less than 3.4 is normal, from 3.4 to less than 4.2 is frequent, and above 4.2 is very frequent. 
The feedbacks show that when the ethnic minorities encounter difficulties, they often use the method of self-solving at a quite regular rate (the level of feedback focuses around very often); other ways of solving problems are at the average level, in which it is worth noting the role of the local authorities and local unions is quite low. From the findings of go visiting and being visited and problem-solving, it is found that the role of the local government and association has been identified as being quite low.

In term of factor analysis, it has been divided into two groups: self-resolution (one variable) and asking for supports (the other seven variables). The trend of self-solving by ethnic minorities (mean = 4.48) is clearer than asking for supports (mean $=2.27$ ). When analyzing the differences between regions, the mean value of these two groups of factors is expressed as the following table:

Table 6: Method of self-solving problems by ethnic minorities: factor analysis

\begin{tabular}{llllll}
\hline & Group (mean) & Mean & Son La & Dak Lak & Binh Duong \\
\hline 1 & Self-solving & 4.28 & 4.40 & 4.19 & 4.13 \\
\hline 2 & Asking for supports & 2.27 & 2.57 & 2.57 & 1.72 \\
\hline
\end{tabular}

It can be seen that ethnic minorities in Son La both have the highest level of self-resolving (at very often) and asking for supports (closed to normal levels). In contrast, the ethnic minorities in Binh Duong show the lower levels in both ways of problem-solving and ask for supports in their life. 4.4. The extent to which they are invited and attend the activities to strengthen social networks

Table 7: Level of social network participation

\begin{tabular}{|c|c|c|c|c|c|c|c|}
\hline & \multirow{2}{*}{ Social networks } & \multirow{2}{*}{ Being invited (\%) } & \multicolumn{5}{|c|}{ Statistics } \\
\hline & & & Min & Max & Mean & SD & Mode \\
\hline 1 & Neighbourhood meeting & $43 \cdot 3$ & 1 & 5 & 2.76 & 1.48 & 1 \\
\hline 2 & Local election & 75.1 & 1 & 5 & 2.96 & 1.19 & 3 \\
\hline & Local festivals & 41.7 & 1 & 5 & 2.53 & 1.21 & 3 \\
\hline 4 & Local cultural tourism & 35.4 & 1 & 5 & 2.23 & 1.01 & 1 \\
\hline 5 & Workplace cultural tourism & 26.8 & 1 & 5 & 2.07 & 1.08 & 1 \\
\hline 6 & Donations & 26.8 & 1 & 5 & 2.10 & 1.10 & 1 \\
\hline 7 & Clubs & 8.7 & 1 & 5 & 1.68 & 0.94 & 1 \\
\hline 8 & Local unions & 18.6 & 1 & 5 & 1.88 & 1.01 & 1 \\
\hline 9 & Home village associations & 10.4 & 1 & 5 & 1.67 & 0.92 & 1 \\
\hline
\end{tabular}

From the responses in Table 7 , it can be seen that the most invited activities for ethnic minorities are local election (75.1\%) and neighbourhood meetings (43.3\%). In the ethnic minorities' participation in their social networks, almost are at the level of infrequent, except for local election at very frequent, and neighbourhood meetings at the average level. It is also found that the ethnic minorities are being invited more; their participation seems to be higher. There are three networks with less invitation to participate, such as local club, local unions and home village association, which are also those networks with their participation at the lowest level.

When analysing the differences between regions to identify the gaps in participation in these community activities, the statistics show that with these 9 activities, ethnic minorities in Lao Cao have participated more than those in Dak Lak and Binh Duong, with respective mean values at 3.15, 2.80 and 1.64. Ethnic minority women participate at higher than those men (2.56 verse 2.48 ). In the age groups, the middle-aged group has a higher participation rate than the others with the mean values at 2.63 compared to 2.53 for those at 45 years old and above, and 2.44 for those under 30 years old. 
Table 8 describes the activities by ethnic minorities in the leisure time in the urban:

Table 8: Preferred activities by ethnic minorities in the leisure time

\begin{tabular}{|c|c|c|c|c|c|c|c|}
\hline & & $\mathrm{N}$ & Min & Max & Mean & $\mathrm{SD}$ & Mode \\
\hline 1 & Chat with friends & 593 & 1 & 5 & 3.38 & 1.03 & 3 \\
\hline 2 & Sleep or rest & 593 & 1 & 5 & 3.84 & 0.87 & 3 \\
\hline 3 & Internet & 589 & 1 & 5 & 1.80 & 0.99 & 1 \\
\hline 4 & Cooking, drinking & 584 & 1 & 5 & 2.53 & 1.04 & 3 \\
\hline 5 & Friend/relative visitings & 589 & 1 & 5 & 2.70 & 1.05 & 3 \\
\hline 6 & Readings & 589 & 1 & 5 & 2.20 & 1.25 & 1 \\
\hline 7 & Going to church/temple & 590 & 1 & 5 & 2.71 & 1.44 & 1 \\
\hline 8 & Hanging around & 589 & 1 & 5 & 2.38 & 1.11 & 3 \\
\hline 9 & Watch TV & 586 & 1 & 5 & 3.17 & 1.39 & 3 \\
\hline 10 & Go shopping & 590 & 1 & 5 & 2.48 & 1.12 & 3 \\
\hline 11 & Going to the home village & 591 & 1 & 5 & 2.41 & 1.10 & 3 \\
\hline
\end{tabular}

There are two activities that ethnic minorities often use during their leisure time are sleeping/resting and chatting with friends, while the most infrequent activity is searching the internet. Some other activities are at less frequent level, such as readings, hanging around, or come home village to rest. From the information in table 8 , it is found that ethnic minorities in urban, after a long working time, are afraid of spending more time in entertainment activities. The Cronbach's Alpha coefficient of these 11 variables is 0.769 ; it shows that the content of these variables is consistent with the whole research content. At the same time, when running the factor analysis, with Varimax rotation, the KMO coefficient is 0.793 , with Barlette's significant level at 0.000 , so these data can be analysed and evaluated statistically. So, these 11 variables are divided into three groups, with an extracted variance of 60.47 , it means that factor analysis can explain over $60 \%$ of the total sample with the load factor as a followed table:

Table 9: Factor analysis of the use of leisure time among ethnic minorities

\begin{tabular}{l|c|c|c}
\hline & Group 1 & Group 2 & Group 3 \\
\hline Friend/relative visitings & .774 & & \\
\hline Going to church/temple & .741 & & \\
\hline Watch TV & .729 & & \\
\hline Hanging around & .669 & & \\
\hline Go shopping & .542 & & \\
\hline Cooking and drinking & .539 & & \\
\hline Going to the home village & & .725 & \\
\hline Internet & & .701 & .795 \\
\hline Readings & & .701 & .531 \\
\hline Sleeping, resting & & & 3.61 \\
\hline Chatting with friends & 2.67 & 2.14 & \\
\hline Mean & & & \\
\hline KMO & & & \\
\hline Extracted variance & & & \\
\hline
\end{tabular}


It can be seen that the ethnic minorities in this study tend to perform activities in terms of resting in their free time or chatting with friends at higher frequent level, but in the aspect of resting and relaxing by searching and updating information or returning to the home village is not clearly presented in this study. It shows that ethnic minorities tend to have a clear livelihood in urban currently.

\subsection{Social issues encountered by ethnic minorities}

Table 10: Experiencing social issues in the daily life of ethnic minorities

\begin{tabular}{|c|c|c|c|c|c|c|c|}
\hline & & $\mathrm{N}$ & Min & Max & Mean & SD & Mode \\
\hline 1 & It is difficult to find a stable job & 583 & 1 & 5 & 2.77 & 1.13 & 3 \\
\hline 2 & It is competitive to look for a job & 585 & 1 & 5 & 2.51 & 1.12 & 2 \\
\hline 3 & Lack of working experiences and skills & 583 & 1 & 5 & 2.34 & 1.16 & 1 \\
\hline 4 & Hard and dangerous job & 579 & 1 & 5 & 2.21 & 1.09 & 1 \\
\hline 5 & Being mistreated by an employer & 585 & 1 & 5 & 1.90 & 0.95 & 1 \\
\hline 6 & Sexually abused & 581 & 1 & 5 & 1.44 & 0.76 & 1 \\
\hline 7 & Abandoned by local people & 582 & 1 & 5 & 1.55 & 0.77 & 1 \\
\hline 8 & Being underestimated by the local authorities/policemen & 582 & 1 & 5 & 1.57 & 0.82 & 1 \\
\hline 9 & Being bullied/threaten & 583 & 1 & 5 & 1.59 & 0.78 & 1 \\
\hline 10 & Being discriminated & 580 & 1 & 5 & 1.69 & 0.85 & 1 \\
\hline 11 & Stressful in partnership & 566 & 1 & 5 & 2.00 & 0.95 & 1 \\
\hline 12 & The pressure to earn money for the family & 581 & 1 & 5 & 2.58 & 1.21 & 3 \\
\hline
\end{tabular}

Note: the significant level of mean is calculated as: (5-1):5 equals to 0.8 , so the level of less than 1.8 is very infrequent, from 1.8 to less than 2.6 is infrequent, from 2.6 to less than 3.4 is normal, from 3.4 to less than 4.2 is frequent, and above 4.2 is very frequent.

The value of Cronbach's alpha of these 12 variables is 0.901, with KMO coefficient at 0.893 , and Bartlett significance coefficient at 0.000 , it shows that these variables are suitable in the whole study and can be used for factor analysis. Responses in table 10 show that ethnic minorities feel that the most common problems in their life are difficult to find a stable job, pressure on earning money to support family, and highly competitive to look for a job in urban. Responses to other aspects also demonstrate that the living context is quite safe and guaranteed in terms of living condition. With those encountered issues in urban life by ethnic minorities, in analysing the factors, it is found that these 12 issues were divided into two groups as follows:

Table 11: Factor analysis about the life experiences on social issues by ethnic minorities

\begin{tabular}{lll}
\hline & Group 1 & Group 2 \\
\hline Being bullied/threaten & .882 & \\
\hline Being underestimated by the local authorities/policemen & .858 & \\
\hline Abandoned by local people & .848 & \\
\hline Sexually abused & .812 & \\
\hline Being discriminated & .801 & \\
\hline Stressful in partnership & .652 & \\
\hline It is difficult to find a stable job & & .789 \\
\hline It is competitive to look for a job & .882 \\
\hline Lack of working experiences and skills & .858 \\
\hline Hard and dangerous job & .690 \\
\hline Being mistreated by an employer & .573 \\
\hline The pressure to earn money for the family & .585 \\
\hline Mean & & 2.38 \\
\hline KMO & 1.64 & \\
\hline Barlette's $p$ & .893 & \\
\hline Extracted variance & .000 & \\
\hline
\end{tabular}


For group 1, including more variables related to the life experiences in the living areas with the family life, while group 2 covers those issues in an aspect of employment of ethnic minorities. These problems of two sides attract more attention by ethnic minorities in urban life. They identify and tend to the issues related to work more than to those around their life and living context.

In crosstab analysis of regional and gender differences in assessing those problems, ethnic minorities in Lao Cai are more likely to identify those issues related to living context than those in Dak Lak and Binh Duong (with mean value at 1.82 in compared to 1.68 and 1.43 respectively). Meanwhile, the concerns to issues related to the employment of ethnic minority people in Dak Lak and Binh Duong are greater than that of those in Lao Cai (with mean value at 2.43 and 2.47 in compared to 2.17 correspondently). It is found that ethnic minorities in Binh Duong are more interested in employment, while those in Lao Cai pay more attention to living condition and contexts.

\subsection{Experiencing social behaviors}

Table 12: Experiencing social behaviours in the life of ethnic minorities

\begin{tabular}{|c|c|c|c|c|c|c|}
\hline & $\mathrm{N}$ & Min & Max & Mean & SD & Mode \\
\hline 1 I can afford to find a job in the city by myself & 588 & 1 & 5 & 2.85 & 0.87 & 3 \\
\hline 2 To be fear of unfriend attitude by others in the workplace & 587 & 1 & 5 & 2.38 & 0.85 & 2 \\
\hline 3 To be afraid of being discriminated at work & 585 & 1 & 5 & 2.12 & 1.01 & 2 \\
\hline 4 Feeling to be treated fairly in the living context & 583 & 1 & 5 & 3.27 & 1.01 & 3 \\
\hline 5 Feeling to be low confidence in social interaction with local people & 579 & 1 & 5 & 2.40 & 1.01 & 2 \\
\hline 6 Feeling to be afraid while having contact with local government and unions & 585 & 1 & 5 & 2.49 & 1.15 & 2 \\
\hline $\begin{array}{l}7 \text { To be fearful of being not sympathised by medical staff while visiting health } \\
\text { facilities }\end{array}$ & 580 & 1 & 5 & 2.34 & 1.05 & 3 \\
\hline 8 I cannot become a member of this city & 587 & 1 & 5 & 2.11 & 1.18 & 1 \\
\hline
\end{tabular}

Note: the significant level of mean is calculated as: (5-1):5 equals to 0.8 , so the level of less than 1.8 is very infrequent, from 1.8 to less than 2.6 is infrequent, from 2.6 to less than 3.4 is normal, from 3.4 to less than 4.2 is frequent, and above 4.2 is very frequent.

Responses from this table show that ethnic minorities perceive the positive attitudes in their life at a regular level. It is apparent in the variables of "I can afford to find a job in the city by myself; Feeling to be treated fairly in the living context" in looking at the mean and mode values), and the perceived levels with the negative aspects were around less frequent. It can also identify the experience of ethnic minorities quite smoothly in urban life and the workplace. The level of being afraid to face these attitudes is being studied in order to have the mean comparison in general, and the given information shows that the degree of occurred barriers is clearly identified from the ethnic minorities in Binh Duong, which is higher than that of those in Lao Cai and Dak Lak, (with mean value at 2.61 in compared to 2.60 and 2.31 respectively. It shows that local ethnic minorities rarely meet social barriers as those migrated ethnic minorities face in the new urban life.

\section{Discussions and Conclusions}

Firstly, the average number of friends of ethnic minorities is around 8 , which shows that ethnic minorities do not have too many friends; the social networks still narrow in their life in the urban. Thereby, the extent of visits and being visited is not clearly reflected; ethnic minorities tend to be more active in the social relationship. Notably, they are more active in visiting their social networks rather than being visited by them.

Secondly, in the process of experiencing daily life in urban, ethnic minorities often find specific ways to resolve their problems rather than ask for assistance from their social networks and local authorities. Ethnic minorities in Binh Duong show a way of having supports from others to solve 
problems at the very infrequent level, which is much lower than other aspects in having issue solutions. However, the way in which they dealt with problems by themselves is significantly lower than the way those in Lao Cai and Dak Lak did.

Thirdly, in activities at the living contexts, ethnic minorities are invited to participate clearly in those related to election, neighbourhood meeting, while others are at the lower level. In association with the low level of being invited and active local activities' participation, the social networks of ethnic minorities are also weak. There is a strong correlation between being invited and involved in the local events in the living contexts.

Fourthly, ethnic minorities in urban mostly use their leisure time to have rest and relax to reproduce their labour force. Hence, they have low responded rate on participation activities related to entertainment and social relationship's creation. Livelihood aspect is visible in their life experiences. Despite these difficulties, ethnic minorities experienced their life with an optimistic attitude and satisfied with what they have in their real life.

Finally, in order to promote the activities by ethnic minorities in the urban life, which direct them to have social inclusion, the local governments, employers and rented house owners should create activities to attract the participation of ethnic minorities. The direction towards social inclusion is significant (Tran Van Kham 2011) which is the ways to support not only the ethnic minorities to be safe and confident in the urban life but also to promote their role and have more contribution to the community life. There have not been many activities like that in these areas recently.

\section{Acknowledgement}

This research is funded by Vietnam National University, Hanoi (VNU) under project number: QG.18.47

\section{References}

Bardhan P và Udry C. (1999). Development Microeconomics, DOI:10.1093/0198773714.001.0oo1

Be Truong Thanh. (2002) Ethnicity and Direction on Making the Ethnic Policies in the process of industrialization and modernization, Political Publishing House, Hanoi/Vấn đề dân tộc và định hướng xây dựng chính sách dân tộc trong thời kỳ công nghiệp hóa, hiện đại hóa, Nxb Chính trị Quốc gia, Hà Nội.

DFID. (1999). Sustainable Livelihoods Guidance Sheet, Xem ngày 7/9/2016 tại $<$ http://www.ennonline.net/dfidsustainableliving >

Dang Phu Thau (2014). Improving the Ethnic Affairs in the Khmer communities in Southern West of Vietnam, Journal of Ethnic Studies, 161/"Nâng cao hiệu quả công tác dân tộc trong vùng đồng bào dân tộc Khmer Tây Nam Bộ", Tạp chí Dân tộc, số 161, tháng 5/2014.

Dinh Quang, Luong Hong Quang, To Duy Hop (2005), Cultural Life in Urbans and Industrial Zones of Vietnam, Culture and Information Publishing House, Hanoi/ Đời sống văn hoá đô thị và khu công nghiệp Việt Nam, Nxb Văn hóa thông tin, Hà Nội.

Ha Son Nhin (2014), Experiences on Ethnic Affairs, Journal of Ethnic Studies, 163/ Một số kinh nghiệm thực hiện công tác dân tộc ở Gia Lai, Tạp chí Dân tộc, số 163.

Le Bach Duong, Nguyen Thanh Liem. 2011. From rural to urban: social and economic impacts by migration in Vietnam, Social Labour Publishing House, Hanoi/Từ nông thôn ra thành phố: tác động kinh tế xã hội của di cư Việt Nam. NXB Lao động xã hội, Hà Nội.

La Thi Thu Thuy, Nguyen Thi Phuong Hoa (2011). Psychological Changes of Young Rural Workers, Social Sciences Publishing House, Hanoi/ Thay đổi tâm lý của thanh niên công nhân xuất thân từ nông thôn, Nxb Khoa học Xã hội, Hà Nội.

Ngo Thi Trinh (2014) Improve the quality of ethnic minority human resources: the strategic task on staff development, Journal of Ethnic Studies, 163/Nâng cao chất lượng nguồn nhân lực dân tộc thiểu số-nhiệm vụ chiến lược của công tác dân tộ, Tạp chí dân tộc, 163. 
Nguyen Đinh Tuan. (2013). Cultural Changes among the urban communities: Casestudy of DInh Cong and Minh Khai communes in Hanoi, PhD Thesis, Vietnam Academy of Social Science, Hanoi/Biến đổi văn hóa trong cộng đồng dân cư vùng đô thị hóa: Nghiên cứu trường hợp tại phường Định Công và xã Minh Khai, Hà Nội, Luận án TS Nhân học, Viện Hàn lâm Khoa học xã hội, Hà Nội

Nguyen Minh Tuan (2013). Life of Ede ethnic people in Dak Lak province: sociological analysis and comparison, $\mathrm{PhD}$ thesis, Vietnam National University-Hanoi/Đời sống của đồng bào dân tộc Ê đê trên địa bàn tỉnh Đắk Lăk-những phân tích và so sánh xã hội học. Luận án Tiến sĩ xã hội học, ĐHQG Hà Nội, Hà Nội.

Nguyen Quang Đieu (2006). Consideration to the building the cultural life for workers in the industrial zones, Journal of Culture and Ideology, 3/2006/ Hãy quan tâm xây dựng đời sống văn hoá của công nhân các khu công nghiệp, Tạp chí Tư tưởng văn hoá, số 3/2006.

Nguyen Van Chieu (2013). Social Welfare Policies and Role of Government in Implementing Social Welfare Policies in Vietnam, PhD thesis, Vietnam Academy of Social Sciences, Hanoi/Chính sách an sinh xã hội và vai trò của nhà nước trong việc thực hiện chính sách an sinh xã hội ở Việt Nam. Luận án tiến sĩ, Viện hàn lâm KHXH Việt Nam, Hà Nội.

Nguyen Van Du (2006) Current situation and solution to secure the life of workers in industrial zones in Binh Duong, Journal of Social Labour, 287/2006/Thực trạng và giải pháp đảm bảo đời sống người lao động tại các khu công nghiệp, khu chế xuất ở Bình Dương, Tạp chí Lao động xã hội, số 287/2006.

Nguyen Van Nhat (2010). Building and Developing the Culture for Vietnamese Working Class: Theories and Practice, Social Sciences Publising House, Hanoi/Xây dựng và phát triển đời sống văn hoá của giai cấp công nhân Việt Nam: Một số vấn đề lý luận và thực tiễn, Nxb Khoa học Xã hội, Hà Nội.

Nguyen Van Quyet (2013). Research on Cultural Changes of Agricultural and Rural Communities in the development process of industrial zones, PhD thesis, Vietnam Institute of Culture and Arts, Hanoi/Nghiên cứu sự biến đổi văn hóa của các cộng đồng nông nghiệp - nông thôn trong quá trình phát triển các khu công nghiệp, Luận án tiến sĩ Văn hóa học, Viện văn hóa nghệ thuật Việt Nam, Hà Nội.

Nguyễn Văn Sửu (2010). Khung sinh kế bền vững-một cách phân tích toàn diện về phát triển và giảm nghèo, Tạp chí Dân tộc học, số 2, tr.3-12.

Pham Van Duc, Đang Huu Toan, Nguyen Dinh Hoa. (2010). Social Security and Social Hamonization, Social Sciences Publishing House, Hanoi/Vấn đề dân sinh và xã hội hài hòa. NXB Khoa học xã hội, Hà Nội.

Pham Ngoc Phuong (2014). Some Solutions on Improving the quality of human resource of ethnic minorities in Son La province from 2011-2020, Journal of Ethnic Studies, 161/Một số giải pháp nâng cao chất lượng nguồn nhân lực dân tộc thiểu số tỉnh Sơn La giai đoạn 2011-2020, Tạp chí Dân tộc, số 161.

Phan Thi Mai Huong (2010). Psychological Changes of Suburbanians in the urbanisational process, Encyclopedia Publishing House, Hanoi/Những biến đổi tâm lý của cư dân vùng ven đô trong quá trình đô thị hoá, Nxb Từ điển Bách Khoa, Hà Nội.

Ta Thi Doan (2011). Employment of Worker in key industrial zones in Northern of Vietnam: Situation and Policy Implication, Labour Publishing House, Hanoi/ Lao động, việc làm của công nhân trong các khu công nghiệp vùng kinh tế trọng điểm Bắc Bộ: Thực trạng và những hàm ý chính sách, Nxb Lao động, Hà Nội.

GSO (2016). Reports on Researching Project on 53 ethnic minority groups in Vietnam, Hanoi/Báo cáo kết quả nghiên cứu về 53 dân tộc thiểu số ở Việt Nam. (báo cáo thông tin khoa học).

Tran Nguyet Minh Thu (2014). Social Integration in Urbans by the Migrants in Hanoi, PhD thesis, Vietnam Academy of Social Sciences, Hanoi/Quá trình hoà nhập cộng đồng đô thị của người lao động di cư tự do tại Hà Nội. Luận án tiến sĩ, Học viện khoa học xã hội, Hà Nội.

Tran Thanh Nam (2001). Developing Spiritual Life for Khmer in Southern of Vietnam in the Renew Process, PhD thesis, Vietnam Political Academy of Ho Chi Minh, Hanoi/Phát triển đời sống tinh thần của đồng bào dân tộc Khmer Nam Bộ trong công cuộc đổi mới hiện nay. Luận án Tiến sĩ, HVCTQG Hồ Chí Minh, Hà Nội.

Tran Van Binh (2004). Cultures of Ethnic Minorities in North Western: Situation and Problems, Political Publishing House, Hanoi/Văn hóa các dân tộc Tây Bắc: Thực trạng và những vấn đề đặt ra, Nxb Chính trị Quốc gia, Hà Nội.

Tran Van Binh (2006). Cultural Life of Ethnic Minorities in the industrialised and urbanized process, Political Publishing House, Hanoi/Đời sống văn hóa các dân tộc thiểu số trong quá trình công nghiệp hóa, hiện đại hóa,Nxb Lý luận Chính trị, Hà Nội.

Tran Van Chu (2007). Material and Spiritual Life of Workers in the industrial zones, Journal of Political Thoughts, no 9, 2007/Đời sống vật chất và tinh thần của công nhân trong các khu công nghiệp, khu chế xuất, Tạp chí Lý luận chính trị, số 9, 2007.

Tran Van Kham (2011). Research on Social Inclusion: Some directions for Vietnam/Nghiên cứu về hoà nhập xã hội: một số định hướng cho Việt Nam, VNU Journal of Social Sciences and Humanities, Vol.27, no.4, viewed at http://js.vnu.edu.vn/index.php/SSH/article/view/16o7 
Tran Van Kham, Nguyen Van Chieu, Basic Social Services for Ethnic Minority Groups in Urban of Vietnam: Current Situation and Solutions. Humanities and Social Sciences. Vol. 4, No. 6, 2016, pp. 17318o. doi: 10.11648/j.hss.20160406.17

Van Tao (2007). Material and Spiritual Life of Workers in Industrial Zones, Journal of Political Ideology, 9/2007/Đời sống vật chất và tinh thần của công nhân trong các khu công nghiệp, khu chế xuất, Tạp chí Lý luận chính trị, số 9/2007.

Vu Van Phuc. (2012). Social Security in Vietnam toward 2020/An sinh xã hội ở Việt Nam hướng tới 2020. Political Publishing House, Hanoi.

Wattez, EA (1999). Some Aspects of Human Development in Vietnam/Một số vấn đề về phát triển con người ở Việt Nam, Political Publishing House, Hanoi.

World Bank 2012 (2012). Green Growth for all: The way to sustainable development, World Bank, Hanoi/Tăng trưởng xanh cho mọi người: Con đường hướng tới phát triển bền vững. NXB Ngân hàng thế giới, Hà Nội.

UNDP (2011). Social Services for Human Development/ viewed on 10/9/2016 at http://www.undp.org/content/dam/vietnam/docs/Publications/27109_902_UNDP_Final_low_res_file_VN_3 10112.pdf 